\title{
36. ASSESSMENT OF DIATOM AND RADIOLARIAN HIGH- AND LOW-LATITUDE ZONATIONS IN NORTHWEST PACIFIC SEDIMENTS: COMPARISON BASED UPON MAGNETOSTRATIGRAPHY ${ }^{1}$
}

\author{
Lloyd H. Burckle and J. J. Morley, Lamont-Doherty Geological Observatory \\ I. Koizumi, Osaka University \\ and \\ U. Bleil, Ruhr-Universität Bochum²
}

\begin{abstract}
Sediments recovered by the hydraulic piston corer at three northwest Pacific sites (Sites 578, 579, and 580; Fig. 1) have a relatively high accumulation rate ( $>30 \mathrm{~m} / \mathrm{m} . \mathrm{y}$.) and contain a detailed paleomagnetic record. This makes it possible to examine the various biostratigraphic datum levels used in low- and high-latitude siliceous floral/faunal zonations in this transitional setting in order to determine which zonal scheme or combination of schemes provides the most reliable biostratigraphic information for the Neogene and Quaternary in this region of the North Pacific. Most high-latitude diatom species do not penetrate the equatorial regions, although they do occur in subarctic to transitional and occasionally subtropical waters. Significant diachroneity is observed in middle Pleistocene sediments. Long-ranging equatorial Pacific forms are found in the northwest Pacific and their first and last appearances are usually isochronous with the equatorial record. However, both first and last appearances tend to be diachronous for species that have short ranges in low latitudes. All of the biostratigraphic marker species associated with the North Pacific radiolarian zonation are present in sediments at the three Deep Sea Drilling Project sites with each event synchronous with its counterpart in high-latitude sediments. Therefore, the North Pacific faunal zonation can be reliably applied to siliceous sediments across a broad region of the northwest Pacific extending from the subarctic to intermediate latitudes.
\end{abstract}

\section{INTRODUCTION}

A persistent problem in biostratigraphy is our uncertainty in correlating between high and low latitudes, across major oceanic (water mass) boundaries, and between northern and southern high latitude sites. It is easy to understand why such a problem exists. Few stratigraphically useful species are so cosmopolitan that they can be used for long-distance correlation. Indeed, most species that are found useful in biostratigraphy have a regional distribution. A way of solving this problem of long-distance correlation presented itself with the advent of magnetostratigraphy as a supporting tool in biostratigraphy (Opdyke et al., 1966; Hays and Opdyke, 1967). Magnetic reversals are isochronous and therefore are not subject to the vagaries of paleoclimate, paleoceanography, or to changing spatial distributions of microfossils.

In spite of these advances in high-resolution biostratigraphy, there were certain limitations that made it difficult to resolve correlation problems for much of the Tertiary. Chief among these limitations was that conventional piston cores used in these studies rarely penetrated more than $25 \mathrm{~m}$ of sediment. This meant that, unless several cores were pieced together, it was not possible to obtain good, continuous records for even the Neogene, much less the Paleogene. For this reason, the technology

\footnotetext{
${ }^{1}$ Heath, G. R., Burckle, L. H., et al., Init. Repts. DSDP, 86: Washington (U.S. Govt. Printing Office)

2 Addresses: (Burckle, Morley) Lamont-Doherty Geological Observatory, Palisades, NY 10964; (Koizumi) College of General Education, Osaka University, Osaka 560, Japan; (Bleil) Institut für Geophysik, Ruhr-Universităt, 4630 Bochum, Federal Republic of Germany.
}

provided by the hydraulic piston core (HPC) is very important, with recovery an order of magnitude greater than that with the wire-line-supported piston corer. Thus, with such cores a continuous magnetostratigraphy for correlation with floral/faunal datums can be acquired, spanning several million years, in regions with relatively high accumulation rates $(>30 \mathrm{~m} / \mathrm{m}$.y.).

Within this context, the northwest Pacific is a unique area-it is transitional between the tropical Pacific and the subarctic North Pacific, a meeting ground for floral and faunal elements from high and low latitudes, and a crucial area for establishing high-resolution correlation between the equatorial Pacific and the North Pacific. Furthermore, study of this area is essential in establishing a late Neogene correlation scheme for such nearby land areas as Japan, Sakhalin, and Kamchatka.

This chapter uses magnetostratigraphy to determine the relationship of various diatom and radiolarian biostratigraphic datum levels used in low- and high-latitude zonal schemes in late Neogene and Quaternary sedimentary sequences from the northwest Pacific. For the equatorial Pacific, we draw largely from the work of Hays et al. (1969), Opdyke and Foster (1970), Burckle (1972, 1977, 1978), Burckle and Opdyke (1977), Burckle and Trainer (1979), and Theyer et al. (1978). Correlations of magnetostratigraphy with biostratigraphic datum levels were presented by Koizumi (1975a, b) and Hays (1970) for the North Pacific and Barron (1980) for the northwest Pacific. The sedimentary sequences at Sites $578-580$ provide a data set for determining which zonal scheme is appropriate for sediments from this transitional zone in the North Pacific. 


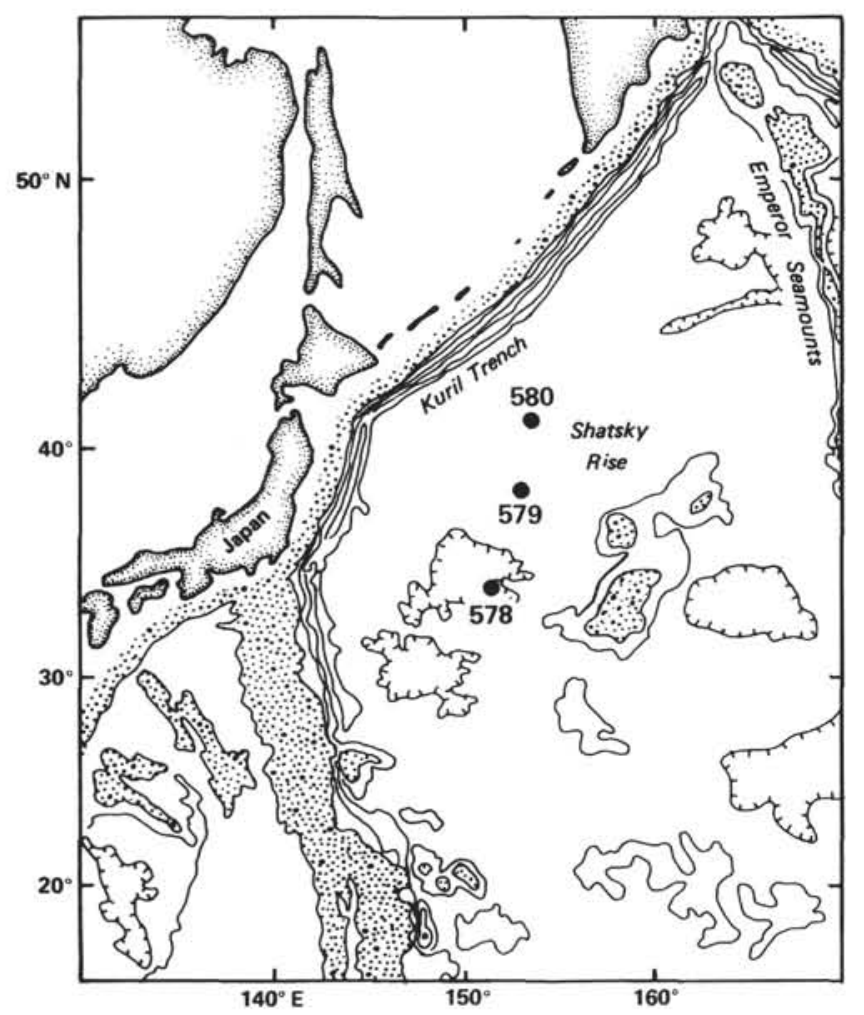

Figure 1. Map of northwest Pacific showing the location of DSDP sites (578-580) used in this study. Areas shallower than 4 km stippled, $5-\mathrm{km}$ contour plain, 6-km contour hachured.

\section{PALEOMAGNETICS}

Vertically oriented samples of about $7 \mathrm{~cm}^{3}$ were taken at intervals ranging from 10 to $50 \mathrm{~cm}$. All Leg 86 materials, with the exceptions noted in Bleil (this volume), were analyzed for their paleomagnetic properties at the Ruhr University, Bochum. Measurements of magnetization intensity and direction were made on a cryogenic magnetometer. The recently revised geomagnetic polarity time scale of Berggren et al. (in press) was used as the basis for interpretation of the downhole polarity sequences and to determine numerical ages for the reversal boundaries (Fig. 2).

\section{DIATOMS}

Figure 2 shows the equatorial Pacific diatom zonation of Burckle $(1972,1978)$, the North Pacific diatom zonation of Koizumi (1975a), and the diatom zonation proposed by Koizumi and Tanimura (this volume) for northwest Pacific Sites 578-580. Key datum levels for both the equatorial Pacific and North Pacific zonations (Table 1) are shown in their stratigraphic position and, using the paleomagnetic stratigraphy for principle time control, we have shown the relative position of these datum levels at Sites 578-580.

In the equatorial Pacific, the oldest datum levels $[1(\mathrm{~T})=$ top of Asterolampra acutiloba and $2(\mathrm{~B})=$ base of Nitzschia jouseae] appear to be isochronous between low latitudes and Site 578. However, Sites 579 and 580 did not penetrate sediments of equivalent age. Koizumi (1975a) does not report either of these diatoms in his North Pacific zonation.

The next equatorial Pacific datum level $[3(\mathrm{~B})=$ base of Rhizosolenia praebergonii] is diachronous between low latitudes and Site 578. Datum level 3 occurs in the middle of the Gauss Chron in the equatorial Pacific (Burckle, 1972) and in the upper part of the Gauss Chron at Site 578. It occurs in even younger sediments (lower part of the Matuyama) at Site 579 but is isochronous between Sites 579 and 580. Koizumi (1975a) does not report this datum level in his North Pacific zonation.

The last appearance of Nitzschia jouseae $[=4(T)]$ occurs in the upper part of the Gauss Chron in equatorial Pacific sediments. This datum is isochronous between low latitudes and Sites $578-580$ and is more or less coincidental with the last occurrence of the high latitude form, Denticulopsis kamtschatica (high latitude North Pacific datum level 2(T); Koizumi, 1975a; Koizumi and Tanimura, this volume).

The next youngest datum $[5(\mathrm{~T})=$ top of Thalassiosira convexa] occurs midway between the top of the Gauss Chron and the base of the Olduvai Event. This datum is isochronous between low latitudes and Sites 578-580. However, in the subarctic North Pacific, Koizumi (1975a) records the last appearance of this form some 200,000 yr. earlier, just above the top of the Gauss Chron. This is consistent with the results of Donahue (1970), who also found that the disappearance of this species in high latitudes precedes that at lower and intermediate latitudes.

One first appearance datum [6(B) $=$ base of Pseudoeunotia doliolus] occurs within the Olduvai Event. This datum is not isochronous between low latitudes and any of the northwest Pacific sites. This may be due to the rarity of the species in the early part of its range; it does not become common to abundant until later in the record. Thus, the level at which the first appearance is drawn may be strictly a function of how much time is spent searching the slide.

The last appearance of Rhizosolenia praebergonii $[=7(\mathrm{~T})]$ occurs just above the Olduvai Event in low latitudes. This datum becomes progressively older in the northwest Pacific until, at Site 580, it is near the last appearance of Thalassiosira convexa $[=5(\mathrm{~T})]$. The last appearance of Nitzschia reinholdii $[=8(\mathrm{~T})]$ appears to be isochronous between low latitudes and the higher latitude North Pacific. In an earlier paper, Koizumi (1975b) suggested that this datum may be slightly diachronous but it is not possible to determine this within the resolution provided by the present paleomagnetic measurements (but see Sancetta, this volume).

Eleven datum levels from the subarctic North Pacific zonation were selected for comparison with Sites 578580 and the equatorial Pacific (Fig. 2). The first appearance of Denticulopsis seminae var. fossilis $[=1(\mathrm{~B})]$ occurs in the middle of the Gilbert Chron in the North Pacific. However, this first appearance is diachronous with respect to transitional and subtropical waters (Sites 578 and 579) and is entirely absent from the equatorial regions. The Denticulopsis kamtschatica last appearance datum $[=2(T)]$ is isochronous between the North Pacific and Sites 578-580. It does not occur in low latitudes. 


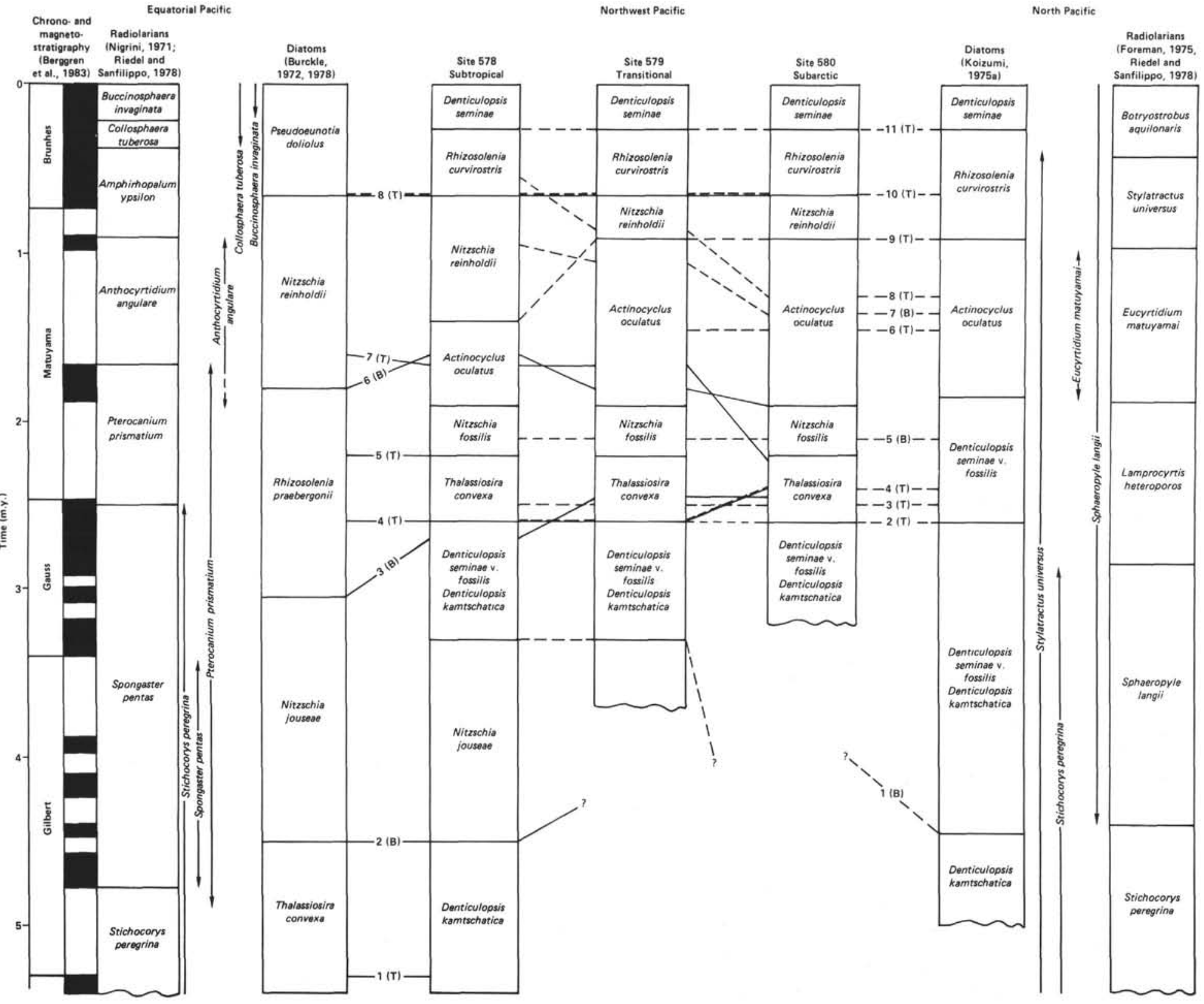

Figure 2. Diatom and radiolarian correlation between the equatorial, northwest, and North Pacific using paleomagnetics as a control (see Bleil, this volume for paleomagnetic stratigraphies of Sites 578-580). Numbers and letters (B and T) represent first appearance (B) and last occurrence (T) of diatom datum levels. These datum levels are explained in the text. Solid lines between sites represent diatom datum levels that originated in the equatorial Pacific; dashed lines between sites represent diatom datum levels that originated in the North Pacific. Diatom zonations at Sites 578-580 proposed by Koizumi and Tanimura (this volume). 
Table 1. Diatom datum levels used in Figure 2.

Equatorial Pacific datum levels

1(T) Disappearance of Asterolampra acutiloba

2(B) Appearance of Nitzschia jouseae

3(B) Appearance of Rhizosolenia praebergonii

4(T) Disappearance of Nitzschia jouseae

5(T) Disappearance of Thalassiosira convexa

6(B) Appearance of Pseudoeunotia doliolus

7(T) Disappearance of Rhizosolenia praebergonit

8(T) Disappearance of Nitzschia reinholdii

High latitude North Pacific datum levels

1(B) Appearance of Denticulopsis seminae var. fossilis

2(T) Disappearance of Denticulopsis kamtschatica

3(T) Disappearance of Bogorovia tatsunokuchiensis

4(T) Disappearance of Nitzschia jouseae

5(B) Appearance of Actinocyclus oculatus

6(T) Disappearance of Thalassiosira antiqua

7(B) Appearance of Rhizosolenia curvirostris

8(T) Disappearance of Denticulopsis seminae var. fossilis

9(T) Disappearance of Actinocyclus oculatus

10(T) Disappearance of Nitzschia reinholdii

11(T) Disappearance of Rhizosolenia curvirostris

This datum is nearly coincidental with the last occurrence of $N$. jouseae [equatorial Pacific datum level 4(T)] (Fig. 2).

The last occurrence of Bogorovia tatsunokuchiensis $[=3(\mathrm{~T})]$ occurs just above the Gauss Chron at Site 580 and appears to be isochronous at both Sites 578 and 579. This species is not reported from the equatorial $\mathrm{Pa}-$ cific. The next datum level above this is the last occurrence of $N$. jouseae $[=4(\mathrm{~T})]$.

The first occurrence of Actinocyclus oculatus [ $=5(\mathrm{~B})$ ] occurs midway between the top of the Gauss Chron and the base of the Olduvai Event. This datum appears to be isochronous between subarctic and subtropical sites, although it does not penetrate into the equatorial regions. The last occurrence of Thalassiosira antiqua $[=6(T)]$ is found only at Sites 579 and 580; the species did not extend into the subtropical gyre or the equatorial regions. Although Figure 2 shows this datum to be isochronous between Sites 579 and 580 , there is some suggestion in our data (Koizumi and Tanimura, this volume) that the last occurrence of $T$. antiqua at Site 579 is earlier than at Site 580 .

The next two datum levels are both diachronous with respect to lower latitudes. The first occurrence of Rhizosolenia curvirostris $[=7(\mathrm{~B})]$ occurs midway between the Olduvai and Jaramillo events in the northern transition zone (Site 580), just below the Jaramillo Event in southern transitional waters (Site 579), and directly below the Jaramillo Event in the subtropics (Site 578). The next youngest datum level [disappearance of Denticulopsis seminae var. fossilis $=8(\mathrm{~T})$ ] persisted longer in the subtropics. At Site 580, this datum level occurs midway between the Olduvai and Jaramillo events while in the subtropics (Site 578) it occurs in the middle of the Brunhes Chron. It is not observed in equatorial regions. It should also be pointed out that there is frequently some difficulty in differentiating $D$. seminae from $D$. seminae var. fossilis near the extinction level of the latter form. This may account for differences in the literature on the placement of this datum level.
The last appearance of Actinocyclus oculatus [ $=9(\mathrm{~T})]$ is isochronous between Sites 580 and 579 but occurs earlier at Site 578. The difference in this datum level between Sites 579 and 578 is quite significant (Fig. 2). The last two datum levels are isochronous within the limits of the paleomagnetic method. $N$. reinholdii $[=10(\mathrm{~T})]$ last occurs in the lower part of the Brunhes Chron in both high and low latitudes while $R$. curvirostris [ = 11(T)] disappears in the upper part of the Brunhes Chron at all three sites, never extending into the equatorial Pacific.

\section{RADIOLARIANS}

Separate radiolarian zonations have been devised for the equatorial and North Pacific sediments of Neogene through Quaternary age (Fig. 2). The zonation for the equatorial Pacific is based on work by Nigrini (1971) and Riedel and Sanfilippo (1978), while that for the North Pacific is from Foreman (1975) and Riedel and Sanfilippo (1978).

Although a majority of the species that define the high latitude zonation are present in low-latitude sediments, the two zonal schemes are based almost entirely upon different biostratigraphic datum levels. Specific zones under the equatorial Pacific scheme occupy intervals of geologic time relatively similar to those in the North Pacific zonation, except for the latest Quaternary (last 400,000 yr.) where the low-latitude zonation contains two zones versus only one in the high-latitude zonation. The one exception to the similar placement of zonal boundaries occurs in the late Pliocene sequence where Stichocorys peregrina defines a boundary in both zonal systems. In the equatorial Pacific zonation, the top of the $S$. pentas zone is based on the last appearance of $S$. peregrina which occurs in tropical Pacific sediments near the top of the Gauss Chron (Theyer et al., 1978). In North Pacific sediments, however, this same event, which marks the boundary between the Sphaeropyle langii and Lamprocyrtis heteroporos zones occurs at approximately 2.85 m.y. ago (Berggren et al., 1983). Therefore, Stichocorys peregrina appears to have inhabited tropical Pacific waters for several thousand years after it disappeared from the North Pacific.

The sediments recovered at Sites 578-580 contain an abundant siliceous fauna with biostratigraphic species diagnostic of the North Pacific zonation. Based upon correlation with magnetostratigraphy, the biostratigraphic events defining specific zones of the North Pacific zonation are synchronous at all three sites. Of the species that define the equatorial Pacific zonation, only $S$. peregrina was present in any abundance in sediments at all sites. A few specimens of Pterocanium prismatium were identified in sediments near the top of its range at Sites 578 and 580. These data indicate that the North Pacific zonation, with its associated datum levels, can be consistently applied to sediments across a broad latitudinal range in the Pacific extending from high-latitude subarctic regions into the mid-latitude subtropics.

\section{CONCLUSIONS}

Using magnetostratigraphy for time control, a comparison was made of various diatom and radiolarian zonations and their associated datum levels for the equato- 
rial Pacific, the northwest Pacific, and the North Pacific in sediment sequences at three northwest Pacific sites (578-580). Few North Pacific diatoms penetrated into the equatorial regions and vice versa. Species with a short range in equatorial regions tend to show the greatest degree of diachroneity into higher latitudes. Interestingly, at least one species (D. seminae var. fossilis), has its longest range in subtropical and transitional waters. The radiolarian biostratigraphic datum levels at all three sites are synchronous with their counterparts in higher latitude sediments, indicating that the North Pacific radiolarian zonation can be applied to sediments in this transitional region.

\section{ACKNOWLEDGMENTS}

We thank Constance Sancetta and Audrey Wright for carefully reviewing the manuscript and offering many useful suggestions, both as to style and content. This work was supported by NSF Grant OCE 7820885 (LHB) and the Deutsche Forschungsgemeinschaft (UB).

\section{REFERENCES}

Barron, J. A., 1980. Lower Miocene to Quaternary diatom biostratigraphy of Leg 57, off northeastern Japan, Deep Sea Drilling Project. In Scientific Party, Init. Repts. DSDP, 56, 57, Pt. 2:Washington (U.S. Govt. Printing Office), 641-685.

Berggren, W. A., Kent, D. V., and Flynn, J. J., in press. Paleogene geochronology and chronostratigraphy. In Snelling, N. J. (Ed.), Geochronology and the Geological Record. Geological Society of London, Spec. Pap.

Burckle, L. H., 1972. Late Cenozoic planktonic diatom zones from the eastern equatorial Pacific. Nova Hedwigia, 39:217-248.

,1977. Pliocene and Pleistocene diatom datum levels from the equatorial Pacific. Quat. Res., 7:330-340.

, 1978. Early Miocene to Pliocene diatom datum levels for the equatorial Pacific. Proc. Working Group on Biostratigraphic Datum Planes of the Pacific Neogene, 2nd, Bandung, Indonesia, pp. 25-44.

Burckle, L. H., and Opdyke, N. D., 1977. Late Neogene diatom correlations in the circum-Pacific. Proc. Int. Congr. Pacific Neogene Strat., 1st, Tokyo, pp. 255-284.
Burckle, L. H., and Trainer J., 1979. Late Pliocene diatom datum levels in the central Pacific. Micropaleontology, 25:281-293.

Donahue, J., 1970. Diatoms as Quaternary biostratigraphic and paleoclimatic indicators in high latitudes of the Pacific ocean [Ph.D. dissert.]. Columbia University, New York.

Foreman, H. P., 1975. Radiolaria from the North Pacific, Deep Sea Drilling Project, Leg 32. In Larson, R. L., Moberly, R., et al, Init. Repts. DSDP, 32: Washington (U.S. Govt. Printing Office), 579-676.

Hays, J. D., 1970. Stratigraphy and evolutionary trends of radiolaria in north Pacific deep-sea sediments. In Hays, J. D. (Ed.), Geological Investigations of the North Pacific. Mem. Geol. Soc. Am., 126:185-218.

Hays, J. D., and Opdyke, N. D., 1967. Antarctic radiolaria, magnetic reversals and climatic change. Science, 158:1001-1011.

Hays, J. D., Saito, T., Opdyke, N. D., and Burckle, L. H., 1969. Pliocene-Pleistocene sediments of the equatorial Pacific: Their paleomagnetic, biostratigraphic and climatic record. Geol. Soc. Am. Bull., 80:1481-1513.

Koizumi, I., 1975a. Late Cenozoic diatom biostratigraphy in the circum-north Pacific region. J. Geol. Soc. Japan, 81:611-627.

1975b. Diatom events in late Cenozoic deep-sea sequences in north Pacific, J. Geol. Soc. Japan, 81:567-577.

Nigrini, C., 1971. Radiolarian zones in the Quaternary of the equatorial Pacific ocean. In Riedel, W. R., and Funnell, B. M. (Eds.), The Micropaleontology of the Oceans: London (Cambridge Univ: Press), pp. 443-461.

Opdyke, N. D., and Foster, J., 1970. The paleomagnetism of cores from the north Pacific, In Hays, J. D. (Ed.), Geological Investigations of the North Pacific. Mem. Geol. Soc. Am., 126:83-119.

Opdyke, N. D., Glass, B., Hays, J. D., and Foster, J., 1966. A paleomagnetic study of Antarctic deep-sea cores. Science, 154:349-357.

Riedel, W. R., and Sanfilippo, A., 1978. Stratigraphy and evolution of tropical Cenozoic radiolarians. Micropaleontology, 24:61-96.

Theyer, F., Mato, G. Y., and Hammond, S. R., 1978. Paleomagnetic and geochronologic calibration of latest Oligocene to Pliocene radiolarian events. Mar. Micropaleontol., 3:377-395.

Date of Initial Receipt: 21 February 1984

Date of Acceptance: 20 August 1984 